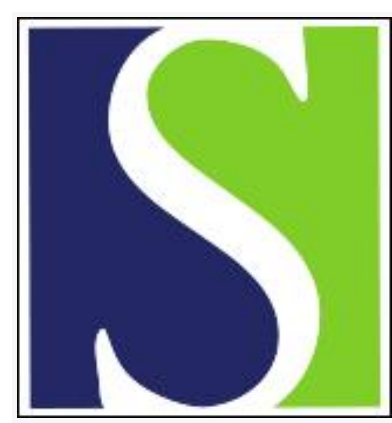

Scand J Work Environ Health 1991;17(1):60-64

https://doi.org/10.5271/sjweh.1733

Issue date: Feb 1991

Studies of biological and chemical monitoring of low-level exposure to ethylene oxide.

by Sarto F, Tornqvist MA, Tomanin R, Bartolucci GB, Osterman-Golkar SM, Ehrenberg L

Affiliation: Institute of Occupational Medicine, Padova University, ULSS n 21 of Veneto, Italy.

This article in PubMed: www.ncbi.nlm.nih.gov/pubmed/2047808

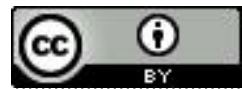




\title{
Studies of biological and chemical monitoring of low-level exposure to ethylene oxide
}

\author{
by Franco Sarto, MD, ${ }^{1}$ Margareta $\AA$ Törnqvist, PhD, ${ }^{2}$ Rosella Tomanin, ScD, ${ }^{1}$ \\ Giovanni B Bartolucci, MD, ${ }^{1}$ Siv M Osterman-Golkar, $\mathrm{PhD},{ }^{2}$ Lars Ehrenberg, $\mathrm{PhD}{ }^{2}$
}

\begin{abstract}
SARTO F, TÖRNQVIST MÅ, TOMANIN R, BARTOLUCCI GB, OSTERMAN-GOLKAR SM, EHRENBERG L. Studies of biological and chemical monitoring of low-level exposure to ethylene oxide. Scand $J$ Work Environ Health 1991;17:60-64. Ten sanitary workers exposed to concentrations of ethylene oxide below $1 \mathrm{ppm}$ were studied to determine whether effects could be observed at low exposure levels. A significant increase in the number of sister chromatid exchanges in cultured lymphocytes was found only for five subjects with relatively high exposure in the sterilization area. However, it was not possible to separate clearly the effect of smoking from that of ethylene oxide exposure. No increase in the frequencies of micronuclei in lymphocytes and buccal cells was found. The level of 2-hydroxyethyl adducts to the N-terminal valines in hemoglobin responded in a reliable fashion to chronic ethylene oxide exposure and smoking. Furthermore, measurement of levels of 2 -hydroxyethyl adducts to the $\mathrm{N}$-terminal valines in hemoglobin made it possible to reconstruct the dynamics of a leakage of ethylene oxide which involved three workers.
\end{abstract}

Key terms: hemoglobin adducts, micronuclei, occupational exposure, sister chromatid exchanges.

Previous studies (1) have shown that chronic exposure to ethylene oxide (EtO) at concentrations of around $10 \mathrm{ppm}$ as the time-weighted average (TWA) for an 8-h workday caused a significant increase in the frequencies of sister chromatid exchanges and chromosome aberrations in peripheral lymphocytes. With the use of a test for sister chromatid exchanges, a doseeffect relationship was also demonstrated for an 8-h TWA range of $0.2-20 \mathrm{ppm}$ (2). These data showed that the occupational exposure limit of $1 \mathrm{ppm}$ recently adopted in many countries may still be critically high. - This statement is valid provided that the demonstration of sister chromatid exchanges, the association of which with health risk is still unknown, is considered to be unacceptable.

In the present paper we have examined data from the environmental and biological monitoring of 10 sanitary workers exposed to concentrations of EtO below $1 \mathrm{ppm}$ to determine whether effects could be observed at this low exposure level, which is still present in modern sterilizing units. Three of the workers had also had an accidentally raised exposure of short duration. The following methods for environmental and biological monitoring were used: (i) personal air sampling for a workshift (external dose), (ii) degree of alkylation of hemoglobin (as a measure of tissue dose), (iii) determination of sister chromatid exchanges and

1 Institute of Occupational Medicine, Padova University ULSS n 21 of Veneto, Padova, Italy.

2 Department of Radiobiology, Stockholm University, Stockholm, Sweden.

Reprint requests to: Dr F Sarto, SPISAL - ULSS n 21 del Veneto, Via Ospedale 22, I-35100 Padova, Italy. micronuclei in cultured peripheral lymphocytes and micronuclei in buccal exfoliated cells (biological effects).

\section{Materials and methods}

\section{Work environment and determination of ethylene} oxide

The studied sterilizing unit consisted of a sterilization room and a preparation area. The sterilization area was equipped with two sterilizers (Sterivac $400 \mathrm{C}$ and Sterivac $400 \mathrm{~B}, 3 \mathrm{M}$ ) which used undiluted EtO and three degasifier cabinets, where all sterilized supplies were stored. A mechanical continuous air suction system guaranteed 10 air changes $/ \mathrm{h}$. In the case of gas leakage an additional aspirator was automatically switched on to increase the ventilation to 30 air changes/h. The subject group worked $6.5 \mathrm{~h} / \mathrm{d}, 6 \mathrm{~d} /$ week in this unit. The average amount of EtO used per week, calculated for the last five weeks, was 3170 (SD 570) g. Exposure to EtO was determined by means of 15 personal air samples taken during a work period $(6.5 \mathrm{~h})$. We used jumbo-type activated charcoal tubes (SKC Inc, Eighty Four, Pennsylvania, United Sates) connected to personal sampling pumps functioning at a constant flow rate of $100 \mathrm{ml} / \mathrm{min}$. The tubes were replaced every $2 \mathrm{~h}$. EtO was immediately desorbed in carbon disulfide and determined by gas chromatography (3).

Three days before the blood sampling a leakage of EtO from a sterilizer had involved three workers. The first subject (E1), working in the sterilization room, smelled the characteristic etherlike odor of EtO simultaneously with the release of the alarm signal and the 
switching on of the supplement aspirator. The acute exposure, presumably around $700 \mathrm{ppm}$, lasted no more than $10 \mathrm{~s}$. The second subject (E7), working in the preparation area, helped the first subject to get out of the sterilization room and escorted her to the first-aid station. The third subject (E9), once the alarm stopped, took the place of the first subject in the sterilizing room and worked there for the rest of the day $(3 \mathrm{~h})$. The exposure doses due to the leak were presumed to decrease in the order E9>E1 $>$ E7 (the presumed exposure of E7 had been very low, being limited to inhalation of expired air from E1).

\section{Subjects}

Five subjects working in the sterilization area (E1-E5) and five subjects working in the preparation area (E6-E10) were studied (see table 1). The reference group was composed of 10 volunteer nurses (R1-R10) working in medical wards of the same hospital. They were of the same sex and similar ages as the exposed subjects and had similar smoking habits. Subject E3, who smoked 15 cigarettes/d and did not inhale the smoke, was paired with a referent (R3) who smoked 6 cigarettes/d.

\section{Cytogenetic methods}

Sister chromatid exchanges. For each subject two replicate cultures of lymphocytes were prepared through the addition of $300 \mu 1$ of whole blood to $5 \mathrm{ml}$ of complete culture medium containing $25 \%$ fetal bovine serum (FBS) and phytohemagglutinin M (PHA M) (Chromosome Medium 1A ${ }^{\circledR}$, Gibco, New York, United States). 5-Bromodeoxyuridine (Sigma, St Louis, United States) was added at the start to a final concentration of $30 \mu \mathrm{g} / \mathrm{ml}$, and the cultures were processed $74 \mathrm{~h}$ later, colchicine $(0.1 \mu \mathrm{g} / \mathrm{ml})$ being added $3 \mathrm{~h}$ before the harvest. The two replicate cultures were processed together. The preparation of metaphasic chromosomes was performed according to standard methods described elsewhere (4). The differential staining of sister chromatid exchanges was obtained with a fluorochrome plus Giemsa method with some modifications (5). On the average, 50 metaphases (range 48-51) were analyzed per subject.

Micronuclei in lymphocytes. Whole blood $(300 \mu \mathrm{l})$ was added to $5 \mathrm{ml}$ of complete culture medium with FBS and PHA M. Cytochalasin B (Sigma) was added after $42 \mathrm{~h}$ to a final concentration of $3 \mu \mathrm{g} / \mathrm{ml}$, and the lymphocytes were harvested $24 \mathrm{~h}$ later. The cells were prepared as follows: before the fixing, whole blood cultures were treated twice with a solution of ammonium bicarbonate $(0.9 \mathrm{mM})$ and ammonium chloride $(0.132 \mathrm{M})$, which causes the lysis of red cells; white blood cells were then fixed in methanol/acetic acid (3:1), dropped onto iced slides, and stained with Giemsa $(10 \%)$, in phosphate buffer $(\mathrm{pH} 7)$, for $10 \mathrm{~min}$. On an average 1800 binucleated cells per person (range $970-2027$ ) were analyzed, the scoring was made at 500 $X$, and micronucleated cells were analyzed at $1250 \times$.

In the present study we added cytochalasin $B$ at the 42nd hour of culture instead of the 44th (6) or the 48th (7) hour. In preliminary experiments, culturing peripheral lymphocytes from four subjects for 40,42 and $48 \mathrm{~h}$ in the presence of $7.5 \mu \mathrm{g} / \mathrm{ml}$ of 5-bromodeoxyuridine, we found that the percentage of first-division metaphases (counted on 2000 stimulated and unstimulated nuclei) was approximately $0.13,0.15$, and $0.90 \%$, respectively. Furthermore, some second- and third-division metaphases were already present in the cultures (8). Hence we blocked the cytokinesis in the 42 nd hour to reduce the percentage of cells which had already divided before the addition of cytochalasin $\mathbf{B}$.

Micronuclei in buccal exfoliated cells. The slides were prepared as explained elsewhere (8), staining being performed following the Feulgen reaction with Fast Green as contrast. On an average 3000 cells per subject (range $2561-3257$ ) were analyzed. As in the case of the sister chromatid exchanges and micronuclei, blood samples from the exposed workers and the referents were cultured and processed at the same time. All the slides were blindly scored in coded slides by two microscopists, one for the sister chromatid exchanges and another for the micronuclei.

\section{Hemoglobin-adduct measurement}

Preparation of globin samples. Blood samples were collected in heparinized vacuum tubes. Erythrocytes were spun down, washed twice with $0.9 \%$ sodium chloride, and then sent frozen by air to Sweden. The cells were lysed by adding one volume of distilled water. Globin was precipitated with ethyl acetate from an acidified (50 mM hydrochloric acid) solution of 2-propanol/hemolysate (6:1) as described by Mowrer et al (9) and was then stored at $-20^{\circ} \mathrm{C}$.

Derivatization of globin samples. For the determination of adducts to the $\mathrm{N}$-termini (valines) of hemoglobin, samples were derivatized according to an updated version (10) of the N-alkyl Edman method (11). Globin samples $(50 \mathrm{mg})$ were dissolved in $1.5 \mathrm{ml}$ of formamide and $40 \mu \mathrm{l}$ of $1 \mathrm{M}$ sodium hydroxide was added (to adjust the recorded $\mathrm{pH}$ to about 6.8). The internal standard, globin alkylated with deuterium-substituted EtO (12) dissolved in formamide, was added. Seven microliters of the reagent, pentafluorophenyl isothiocyanate (Fluka, Buchs, Switzerland) purified as described by Törnqvist et al (10), was added to the sample solutions, and the derivatizations were carried out overnight at room temperature as the tubes were tilted back and forth. Warming the samples at $45^{\circ} \mathrm{C}$ for $1.5 \mathrm{~h}$ finalized the derivatizations. The samples 
were extracted with $2 \times 2 \mathrm{ml}+1 \mathrm{ml}$ of diethyl ether, and the ether extract was evaporated under a nitrogen stream. The samples were purified by washing with $0.1 \mathrm{M}$ sodium carbonate after the extract was dissolved in toluene as described by Törnqvist et al (11).

Gas chromatographic-mass spectrometric analysis. The gas chromatographic-mass spectrometric analyses of hydroxyethylvaline pentafluorophenylthiohydantoin (HOEtVal-PFPTH) were done with a Finnigan 4500 instrument in the negative ion chemical ionization mode, using methane as the reagent gas and monitoring characteristic fragments as described by Törnqvist et al $(10,11)$. The gas chromatograph was equipped with an on-column injector and a DB- $5(30 \mathrm{~m}, 0.33 \mathrm{~mm}$ inner diameter, $1 \mu \mathrm{m}$ phase thickness) fused silica capillary column (J\&W Scientific Inc, Rancho Cordova, California, United States) coupled to a deactivated fused silica precolumn $(5 \mathrm{~m}, 0.32 \mathrm{~mm}$ inner diameter). The fragments used for quantifying the determined PFPTH were $\mathrm{m} / \mathrm{z} 348$ for HOEtVal-PFPTH and $\mathrm{m} / \mathrm{z}$ 352 for the derivative of the internal standard, $\left({ }^{2} \mathrm{H}_{4}\right)$ HOEtVal-PFPTH. A linear calibration curve was established from calibration samples prepared from a globin $(50 \mathrm{mg} / \mathrm{sample})$ with a low background of HOEtVal, with the addition of globin alkylated artificially with EtO, and the internal standard globin (10).

\section{Statistical analysis}

The averages of the frequencies of the sister chromatid exchanges and the micronuclei determined for the exposed and reference subjects were compared with the t-test for independent series. All the statistical tests were two-sided.

\section{Results}

Table 1 reports the TWA concentrations of EtO measured in the sterilizing unit, essential anamnestic data, and sister chromatid exchange frequencies of the examined subjects. The concentration of EtO found in the preparation area was very low (about 15 times lower than that measured in the sterilization room) and near the limit of detection of the air monitoring method. In the sterilization room, during the unloading of the sterilizers, there was an EtO concentration of tens of parts per million for some minutes and 4.4 ppm for $30 \mathrm{~min}$. In the other phases of work the concentration of EtO dropped to below $1 \mathrm{ppm}$. The exposure 6.5-h TWA of subjects E1-E5 was calculated to be $0.38 \mathrm{ppm}$ since these subjects spent part of their worktime in the preparation area.

The two highest values for the sister chromatid exchanges were determined for smoking subjects with more than 10 years' employment in EtO sterilizing units (E2: 13.7 sister chromatid exchanges/metaphase, E3: 14.3 sister chromatid exchanges/metaphase). The

Table 1. Environmental data, essential anamnestic data, and the frequency of sister chromatid exchanges for the examined subjects. ( $E$ tO $=$ ethylene oxide, TWA $=$ time-weighted average)

\begin{tabular}{|c|c|c|c|c|c|c|c|}
\hline \multirow{3}{*}{ Subject } & \multirow{3}{*}{ Length } & \multicolumn{2}{|l|}{ Exposure } & \multirow{3}{*}{$\begin{array}{c}\text { Age } \\
\text { (years) }\end{array}$} & \multirow{3}{*}{ Cigarettes/day } & \multicolumn{2}{|c|}{$\begin{array}{c}\text { Sister chromatid } \\
\text { exchange/ } \\
\text { metaphase }\end{array}$} \\
\hline & & \multicolumn{2}{|c|}{ EtO concentration } & & & & \\
\hline & & TWA/6.5 h & TWA $30 \mathrm{~min}$ & & & Mean & 政 \\
\hline $\begin{array}{l}\text { E1 } \\
\text { E2 } \\
\text { E3 } \\
\text { E4 } \\
\text { E5 } \\
\text { E6 } \\
\text { E7 } \\
\text { E8 } \\
\text { E9 } \\
\text { E10 }\end{array}$ & $\begin{array}{c}11 \text { years } \\
12 \text { years } \\
11 \text { years } \\
5 \text { years } \\
4 \text { years } \\
1 \text { year } \\
4 \text { years } \\
3 \text { years } \\
2 \text { years } \\
1 \text { month }\end{array}$ & $\begin{array}{ll}0.38 & \mathrm{ppm} \\
0.38 & \mathrm{ppm} \\
0.38 & \mathrm{ppm} \\
0.38 & \mathrm{ppm} \\
0.38 & \mathrm{ppm} \\
0.025 \mathrm{ppm} \\
0.025 \mathrm{ppm} \\
0.025 \mathrm{ppm} \\
0.025 \mathrm{ppm} \\
0.025 \mathrm{ppm}\end{array}$ & $\begin{array}{l}\text { 4.4 ppm } \\
\text { 4.4 ppm } \\
\text { 4.4 ppm } \\
\text { 4.4 ppm } \\
4.4 \mathrm{ppm} \\
. \\
. \\
. \\
. \\
.\end{array}$ & $\begin{array}{l}43 \\
56 \\
35 \\
44 \\
38 \\
32 \\
42 \\
49 \\
33 \\
32\end{array}$ & $\begin{array}{l}\overline{15} \\
15 \\
- \\
- \\
- \\
- \\
-\end{array}$ & $\begin{array}{r}11.7 \\
13.7 \\
14.3 \\
10.7 \\
11.4 \\
8.5 \\
11.0 \\
10.0 \\
9.3 \\
11.0\end{array}$ & $\begin{array}{l}3.5 \\
6.2 \\
4.7 \\
3.9 \\
4.4 \\
3.1 \\
4.1 \\
4.7 \\
4.4 \\
4.4\end{array}$ \\
\hline $\begin{array}{l}\text { E1-E5 } \\
\text { E6-E10 }\end{array}$ & $\begin{array}{l}8.6 \text { years } \\
2.0 \text { years }\end{array}$ & $\begin{array}{l}0.38 \mathrm{ppm} \\
0.025 \mathrm{ppm}\end{array}$ & $4.4 \mathrm{ppm}$ & $\begin{array}{l}43.2 \\
37.6\end{array}$ & $\dot{.}$ & $\begin{array}{l}12.4 \\
10.0\end{array}$ & $\begin{array}{l}1.5 \\
1.1\end{array}$ \\
\hline $\begin{array}{l}\text { R1 } \\
\text { R2 } \\
\text { R3 } \\
\text { R4 } \\
\text { R5 } \\
\text { R6 } \\
\text { R7 } \\
\text { R8 } \\
\text { R9 } \\
\text { R10 }\end{array}$ & $\begin{array}{l}- \\
- \\
- \\
- \\
- \\
- \\
-\end{array}$ & $\begin{array}{l}- \\
- \\
- \\
- \\
- \\
- \\
-\end{array}$ & $\begin{array}{l}- \\
- \\
- \\
- \\
- \\
- \\
-\end{array}$ & $\begin{array}{l}42 \\
53 \\
33 \\
42 \\
35 \\
30 \\
40 \\
53 \\
31 \\
31\end{array}$ & $\begin{array}{l}\overline{15} \\
6 \\
- \\
- \\
- \\
- \\
- \\
-\end{array}$ & $\begin{array}{r}11.4 \\
11.9 \\
11.4 \\
9.8 \\
9.7 \\
10.8 \\
12.4 \\
9.6 \\
10.1 \\
10.8\end{array}$ & $\begin{array}{l}4.1 \\
3.6 \\
3.5 \\
3.2 \\
3.5 \\
3.9 \\
3.8 \\
4.0 \\
3.5 \\
4.3\end{array}$ \\
\hline \multicolumn{8}{|l|}{ Total } \\
\hline $\begin{array}{l}\text { Exposed } \\
\text { Referents }\end{array}$ & $\begin{array}{c}5.3 \text { years } \\
-\end{array}$ & $\dot{-}$ & - & $\begin{array}{l}40.4 \\
39.0\end{array}$ & $\dot{.}$ & $\begin{array}{l}11.2 \\
10.8\end{array}$ & $\begin{array}{l}1.8 \\
1.0\end{array}$ \\
\hline
\end{tabular}


Table 2. Frequencies of micronucleated cells and micronuclei in peripheral blood lymphocytes and buccal exfoliated cells from the exposed and reference subjects.

\begin{tabular}{|c|c|c|c|c|c|c|c|c|c|c|}
\hline \multirow{3}{*}{ Subject } & \multicolumn{6}{|c|}{ Lymphocytes } & \multicolumn{4}{|c|}{ Buccal cells } \\
\hline & \multicolumn{2}{|c|}{$\begin{array}{l}\text { Binucleated } \\
\text { cells }(\% 0)\end{array}$} & \multicolumn{2}{|c|}{$\begin{array}{l}\text { Micronucleated } \\
\text { cells }(\%)\end{array}$} & \multicolumn{2}{|c|}{$\begin{array}{l}\text { Micronuclei } \\
\text { cells }(\% \circ)\end{array}$} & \multicolumn{2}{|c|}{$\begin{array}{l}\text { Micronucleated } \\
\text { cells }(\%)\end{array}$} & \multicolumn{2}{|c|}{$\begin{array}{c}\text { Micronucle } \\
\text { cells }(\%)\end{array}$} \\
\hline & Mean & SD & Mean & SD & Mean & SD & Mean & SD & Mean & SD \\
\hline $\begin{array}{l}\text { Exposed E1-E5 } \\
\text { Exposed E6-E10 }\end{array}$ & $\begin{array}{l}12.13 \\
11.64\end{array}$ & $\begin{array}{l}4.3 \\
7.3\end{array}$ & $\begin{array}{l}11.58 \\
11.53\end{array}$ & $\begin{array}{l}5.5 \\
4.4\end{array}$ & $\begin{array}{l}12.65 \\
13.34\end{array}$ & $\begin{array}{l}5.7 \\
5.1\end{array}$ & $\begin{array}{l}0.58 \\
0.40\end{array}$ & $\begin{array}{l}0.3 \\
0.6\end{array}$ & $\begin{array}{l}0.66 \\
0.60\end{array}$ & $\begin{array}{l}0.3 \\
0.8\end{array}$ \\
\hline $\begin{array}{l}\text { Exposed E1-E10 } \\
\text { Referents }\end{array}$ & $\begin{array}{l}11.88 \\
10.45\end{array}$ & $\begin{array}{l}5.7 \\
4.5\end{array}$ & $\begin{array}{r}11.55 \\
9.52\end{array}$ & $\begin{array}{l}4.7 \\
5.4\end{array}$ & $\begin{array}{l}13.00 \\
11.00\end{array}$ & $\begin{array}{l}5.1 \\
6.3\end{array}$ & $\begin{array}{l}0.49 \\
0.36\end{array}$ & $\begin{array}{l}0.5 \\
0.5\end{array}$ & $\begin{array}{l}0.63 \\
1.00\end{array}$ & $\begin{array}{l}0.6 \\
1.9\end{array}$ \\
\hline
\end{tabular}

mean frequency of sister chromatid exchanges was 12.4 (SD 1.6) per metaphase for subjects E1 through E5 and 10.0 (SD 1.1) for subjects E6 through E10, the difference being statistically significant $(t=2.9, P \approx 0.02)$. In comparisons of subjects $E 1-E 5$ with all the referents and subjects E6-E10 with all the referents, only for the first group was the difference statistically significant $(t=2.4, P<0.03)$. The means of the sister chromatid exchanges for the entire exposed group [11.2 (SD 1.8)] and the reference group [10.8 (SD 1.0)] were not significantly different $(t=0.49, P \approx 0.6)$. When the smokers were excluded from the analysis, the total frequency of sister chromatid exchange per metaphase was even lower for the exposed group than for the referents.

Table 2 presents the frequencies of micronucleated cells and micronuclei per cell in the peripheral blood lymphocytes and buccal cells. For the micronucleated cells in lymphocytes there were no significant differences between subjects $\mathrm{E} 1-\mathrm{E} 5$ and $\mathrm{E} 6-\mathrm{E} 10(\mathrm{t}=0.02$, $P \approx 1$ ), between subjects $E 1-E 5$ and the referents $(t=0.69, P \approx 0.5)$, and between subjects $E 6-E 10$ and the referents $(t=0.71, P \approx 0.5)$. For the micronucleated cells in buccal mucosa there were no significant differences between subjects $\mathrm{E} 1-\mathrm{E} 5$ and $\mathrm{E} 6-\mathrm{E} 10(\mathrm{t}=0.55$, $P \approx 0.6$ ), between subjects $E 1-E 5$ and the referents $(t=0.77, P \approx 0.4)$, and between subjects $E 6-E 10$ and the referents $(t=0.13, P \approx 0.9)$.

For subjects E1, E7, and E9, who were involved in the acute exposure, the first sample had been taken $3 \mathrm{~d}$ after the acute exposure. The analysis of buccal exfoliated cells was repeated 9 and $16 \mathrm{~d}$ after the acute exposure, but we did not find any difference in the repeated samples.

Table 3 summarizes the results of the hemoglobinadduct measurements. The observed average back. ground level of HOEtVal in hemoglobin in nonsmoking, nonexposed subjects (subjects R1, R6, R7, R8), $24 \mathrm{pmol} / \mathrm{g}$, agreed well with observations from Swedish adults (13). The found increments in unexposed smokers (R2, R3, R9) were compatible with increments expected from earlier studies (13) showing $8.5 \mathrm{pmol} / \mathrm{g}$ per cigarette $(0.66 \mathrm{~g}$ tobacco) (14). The expected adduct increment was estimated to be $10.3 \mathrm{pmol} / \mathrm{g}$ per cigarette on the assumption of a consumption of $0.8 \mathrm{~g}$ of tobacco per Italian cigarette.
Table 3. Hemoglobin-adduct levels in the subjects exposed to ethylene oxide and the referents. (HOEtVal = hydroxyethylvaline)

\begin{tabular}{|c|c|c|c|}
\hline Subject & $\begin{array}{l}\text { HOEtVal } \\
\text { (total } \\
\text { pmol/g) }\end{array}$ & $\begin{array}{c}\text { Increment from } \\
\text { tobacco expo- } \\
\text { sure } \\
\text { (pmol/g) }\end{array}$ & $\begin{array}{l}\text { Increment from } \\
\text { exposure to } \\
\text { ethylene oxide } \\
\text { (pmol/g) }\end{array}$ \\
\hline $\begin{array}{l}\text { E1 } \\
\text { E2 } \\
\text { E3 } \\
\text { E6 } \\
\text { E7 } \\
\text { E8 } \\
\text { E9 }\end{array}$ & $\begin{array}{r}290 \\
340 \\
140 \\
180 \\
78 \\
160 \\
430\end{array}$ & $\begin{array}{c}155^{\mathrm{b}} \\
70^{\mathrm{b}} \\
\dot{\cdot} \\
\dot{ }\end{array}$ & $\begin{array}{r}270 \\
160 \\
50 \\
160 \\
50 \\
140 \\
400\end{array}$ \\
\hline $\begin{array}{l}\mathrm{R} 1 \\
\mathrm{R} 2 \\
\mathrm{R} 3 \\
\mathrm{R} 6 \\
\mathrm{R} 7 \\
\mathrm{R} 8 \\
\mathrm{R} 9\end{array}$ & $\begin{array}{r}21 \\
280 \\
88 \\
25 \\
22 \\
26 \\
76\end{array}$ & $\begin{array}{r}256(155)^{\mathrm{c}} \\
64 \quad(60)^{\mathrm{c}} \\
\cdot \\
52 \quad(30)^{\mathrm{c}}\end{array}$ & $\begin{array}{l}. \\
\dot{.} \\
\dot{.} \\
\dot{.} \\
.\end{array}$ \\
\hline
\end{tabular}

a Accidental exposure: E9 highest, E1 intermediate, E7 lowest. (See the text.)

- Expected from values in reference series.

c Increment above average background (24 pmol/g); expected value from $10.3 \mathrm{pmol} \cdot \mathrm{cig}^{-1} \cdot \mathrm{day}^{-1}$, on the assumption of $0.80 \mathrm{~g}$ tobacco smoked per Italian cigarette in parentheses. See reference 13.

The increment from EtO exposure was calculated by subtracting the average background for each subject plus the expected increment from tobacco smoking for the smokers.

\section{Discussion}

The examined sterilization unit, built according to the criteria of the Italian Ministry of Health (15), reflects, on the average, the exposure conditions for the majority of Italian sterilization units, namely, a TWA concentration of EtO of around 1 ppm in the sterilization area and a TWA exposure of the workers of below 1 ppm. In a Swedish study (16) work for $40 \mathrm{~h} /$ week at a TWA level of $1 \mathrm{ppm}$ was found to be associated with $2.4 \cdot 10^{3} \mathrm{pmol} \mathrm{HOEtVal} / \mathrm{g}$ of hemoglobin. The range of adduct levels in our study, even including the accidental exposure, indicates thus that the TWA may have been lower than the measured TWA of $0.38 \mathrm{ppm}$ (at this exposure level the expected adduct content would have been about $750 \mathrm{pmol} / \mathrm{g}$ ). On the other 
hand, the found adduct levels for subjects E6 and E8 were somewhat higher than expected $(60 \mathrm{pmol} / \mathrm{g})$ from the measured TWA $(0.025 \mathrm{ppm})$.

At these low-concentration, long-term exposure levels we did not find any increase in the frequencies of micronuclei in lymphocytes and buccal cells. As for the sister chromatid exchanges, we found a significant increase only in the group working in the sterilization room, with a measured TWA concentration of $0.38 \mathrm{ppm}$. Since the number of examined subjects was very small, it is not possible to separate the effect of smoking clearly from that of the EtO exposure.

None of the cytogenetic tests employed was able to show an effect of low acute exposure to EtO. There was no correlation between the cytogenetic end points and the hemoglobin adduct levels.

As shown in table 3, the level of HOEtVal in hemoglobin from subjects without exposure to EtO, both smokers and nonsmokers, agrees with findings from other studies $(13,17)$. The study confirms the usefulness of hemoglobin adduct measurement as a sensitive monitor of reactive compounds in work environments. In particular the considerably increased values found for subjects E1 and E9, both involved in an accident that caused acute exposure to EtO, made it possible to reconstruct the doses received in the incident.

\section{Acknowledgments}

The study was supported by the Italian Association for Research on Cancer (AIRC), Regione del Veneto, the National Swedish Environment Protection Board, and the Swedish Cancer Society.

\section{References}

1. Sarto F, Cominato I, Pinton AM, et al. Cytogenetic damage in workers exposed to ethylene oxide. Mutat Res 1984;138:185-95.

2. Sarto F, Clonfero E, Bartolucci GB, Franceschi C, Chiricolo M, Levis AG. Sister chromatid exchanges and DNA repair capability in sanitary workers exposed to ethylene oxide: evaluation of the dose-effect relationship. Am J Ind Med 1987;12:625-37.

3. National Institute for Occupational Safety and Health. Manual of analytical methods. 2nd ed. Cincinnati, $\mathrm{OH}$ : National Institute for Occupational Safety and Health 1977. (vol 3, no 9286-1-9).

4. Sarto F, Faccioli MC, Cominato I, Levis AG. Increased incidence of chromosomal aberrations and sister chro- matid exchanges in workers exposed to chromic acid in electroplating factories. Carcinogenesis 1982;3:1011-6.

5. Sarto F, Faccioli MC, Mustari L, Brovedani PG, Levis AG. Factors influencing sister chromatid exchanges in man. In: Foa' V, ed. Occupational and environmental chemical hazards. Chichester: Ellis Horwood, 1987: 424-31.

6. Fenech M, Moley AA. Measurement of micronuclei in lymphocytes. Mutat Res 1985;147:29-36.

7. Sarto F, Tomanin R, Giacomelli L, et al. Evaluation of chromosomal aberrations in lymphocytes and micronuclei in lymphocytes, oral mucosa and hair root cells of patients under antiblastic therapy. Mutat Res 1990; 228:157-69.

8. Sarto F, Finotto S, Giacomelli L, Mazzotti D, Toma$\operatorname{nin} R$, Levis AG. The micronucleus assay in exfoliated cells of the human buccal mucosa. Mutagenesis 1987; $2: 11-7$.

9. Mowrer J, Törnqvist M, Jensen S, Ehrenberg L. Modified Edman degradation applied to hemoglobin for monitoring occupational exposure to alkylating agents. Toxicol Environ Chem 1986;11:215-31.

10. Törnqvist M, Kautiainen A, Gatz RN, Ehrenberg L. Hemoglobin adducts in animals exposed to gasoline and diesel exhausts: 1. alkenes. J Appl Toxicol 1988;8:15970.

11. Törnqvist M, Mowrer J, Jensen S, Ehrenberg L. Monitoring of environmental cancer initiators through hemoglobin adducts by a modified Edman degradation method. Anal Biochem 1986;154:255-66.

12. Farmer PB, Bailey E, Gorf SM, et al. Monitoring human exposure to ethylene oxide by the determination of haemoglobin adducts using gas chromatographymass spectrometry. Carcinogenesis 1986;7:637-40.

13. Törnqvist M. Monitoring and cancer risk assessment of carcinogens, particularly alkenes in urban air [doctoral dissertation]. Stockholm: University of Stockholm, 1989.

14. Persson K-A, Berg S, Törnqvist M, Scalia-Tomba G-P, Ehrenberg L. Note on ethene and other low-molecular weight hydrocarbons in environmental tobacco smoke. Acta Chem Scand B 1988;42:690-6.

15. Ministero della Sanita'. Impiego del gas tossico ossido di etilene per processi di sterilizzazione eseguiti in ospedali e altre strutture sanitarie su materiale destinato ad essere impiegato in campo umano. Roma: Ministero della Sanita', 1981 (Circolare; n 47).

16. Duus U, Osterman-Golkar S, Törnqvist M, Mowrer J, Holm S, Ehrenberg L. Studies of determinants of tissue dose and cancer risk from ethylene oxide exposure. In: Freij L, ed. Proceedings of the symposium on management of risk from genotoxic substances in the environment, Solna: Swedish National Chemicals Inspectorate, 1989:141-53.

17. Törnqvist M, Osterman-Golkar S, Kautiainen A, Jensen S, Farmer PB, Ehrenberg L. Tissue doses of ethylene oxide in cigarette smokers determined from adduct levels in hemoglobin. Carcinogenesis 1986;7:1519-21.

Received for publication: 26 April 1990 